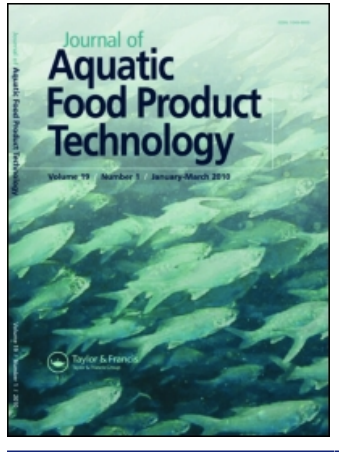

Journal of Aquatic Food Product Technology

ISSN: 1049-8850 (Print) 1547-0636 (Online) Journal homepage: https://www.tandfonline.com/loi/wafp20

\title{
Preparation of Extruded Snacks with Flavored Flour Obtained from the Carcasses of Nile Tilapia: Physicochemical, Sensory, and Microbiological Analysis
}

Alex P. Justen, Maria Luiza Rodrigues de Souza, Antonio R. G. Monteiro, Jane M. G. Mikcha, Eliane Gasparino, Ádina B. Delbem, Maria Regina B. de Carvalho \& Ana P. Del Vesco

To cite this article: Alex P. Justen, Maria Luiza Rodrigues de Souza, Antonio R. G. Monteiro, Jane M. G. Mikcha, Eliane Gasparino, Ádina B. Delbem, Maria Regina B. de Carvalho \& Ana P. Del Vesco (2017) Preparation of Extruded Snacks with Flavored Flour Obtained from the Carcasses of Nile Tilapia: Physicochemical, Sensory, and Microbiological Analysis, Journal of Aquatic Food Product Technology, 26:3, 258-266, DOI: 10.1080/10498850.2015.1136718

To link to this article: https://doi.org/10.1080/10498850.2015.1136718

Accepted author version posted online: 27

May 2016.

Published online: 03 Feb 2017.

Submit your article to this journal $\Longleftarrow \pi$

Џll Article views: 99

View Crossmark data \lceil

Citing articles: 1 View citing articles ๔ 


\title{
Preparation of Extruded Snacks with Flavored Flour Obtained from the Carcasses of Nile Tilapia: Physicochemical, Sensory, and Microbiological Analysis
}

\author{
Alex P. Justen ${ }^{a}$, Maria Luiza Rodrigues de Souza ${ }^{a}$, Antonio R. G. Monteiro ${ }^{b}$, \\ Jane M. G. Mikchac, Eliane Gasparinoa Ádina B. Delbem', Maria Regina B. de Carvalhoe, \\ and Ana P. Del Vescof \\ ${ }^{a}$ Animal Science Department, State University of Maringá, Maringá, Brazil; 'bood Engineering Department, State \\ University of Maringá, Maringá, Brazil; 'Clinical Analyses and Biomedicine Department, State University of Maringá, \\ Maringá, Brazil; 'Embrapa Pantanal, Corumbá, Mato Grosso do Sul, Brazil; 'Food Technology Department, UNESP, \\ Jaboticabal, Brazil; fUniversidade Federal de Sergipe, São Cristóvão, Brazil
}

\begin{abstract}
This study aimed to develop extruded snacks including flour obtained from Nile tilápia carcasses, and then evaluate the chemical composition, colorimetry, thiobarbituric acid reactive substances, and microbiology. There was a significant increase in the levels of crude protein, ether extract, ash, and minerals, as well as a reduction in carbohydrates as more flour was included in the snacks. Increased levels of flavored flour caused reduction in the brightness of snacks. Oxidative rancidity was not detected in snacks. The inclusion of flour improved the nutritional value of extruded snacks without changing sensory characteristics. Microbiologically, the snacks are suitable for human consumption.
\end{abstract}

\section{KEYWORDS}

Corn chips; minerals; smoking; waste filleting

\section{Introduction}

Tilapia is considered to be very important in global aquaculture, as it is very suitable for intensive cultivation. In addition, tilapia is one of the fish species that are most often used for filleting. It is a suitable fish for the filleting industry due to the absence of thorns in the "Y" of your steak, and thus is widely accepted by the consumer market (Hildsorf, 1995).

The waste generated by filleting reaches $60-70 \%$, which constitutes a serious problem for the processing unit as well as for the environment, as this has technological implications for the development of products that can add value to the aquaculture activity (Vidotti and Borini, 2006).

It is important to consider that components of the fish include a high crude protein content (about 20\%), minerals (calcium, phosphorus, and iron), and fat. The fish meat is considered to be a major source of omega-3 fatty acids. Souza (2006) reported that the flour produced from tilapia carcasses contained $32.82 \%$ crude protein, $21.95 \%$ fat, $22.86 \%$ ash, $1.78 \mathrm{~g}$ of calcium per $100 \mathrm{~g}$ of flour, $2.36 \mathrm{mg}$ of iron per $100 \mathrm{~g}$ of flour, and $5.47 \mathrm{mg}$ of phosphorus per $100 \mathrm{~g}$ of flour. The same author mentioned that 23 fatty acids have also been found in tilapia carcasses, including the very important n-3 polyunsaturated fatty acid (PUFA), eicosapentaenoic acid (EPA), and docosahexaenoic acid (DHA). Despite the fact that freshwater fish exhibit lower levels of omega-3 than marine fish (Ogawa and Maia, 1999), this fish remains important in human nutrition.

Of the consumers of fish, children have some of the lowest rates of consumption, which indicates that we need different marketing strategies in order to increase the consumption of fish by this sector. Flavored fish flour can be added to various products of interest, such as extruded snacks (corn 
chips). Because these snacks are very attractive to children and teenagers, including flavored flour means they will ingest a food with better nutritional qualities.

Corn snacks traditionally found in the supermarket are products rich in carbohydrates because they are prepared with corn grits. These corn chips are produced via the extrusion process, which is responsible for the high volume and crispness of the product. After this initial processing, the snacks pass through a flavoring stage in order to be acceptable for consumption. Thus, an alternative would be to enhance this product with increased levels of protein and minerals. Thus, this study aimed to develop extruded snacks with different levels of flavored flour obtained from carcasses of Nile tilapia. The snacks were then analyzed based on their chemical composition, color, water activity, thiobarbituric acid reactive substances (TBARS), oxidative rancidity, as well as for their sensory and microbiological components.

\section{Material and methods}

In the study, 200 carcasses of Nile tilapia (Oreochromis niloticus) from the Smartfish Company (Rolândia, Parana State, Brazil) were used. After filleting the fish according to the standards of the company, the gutted carcasses that would have been discarded were frozen at $-25^{\circ} \mathrm{C}$. To prepare the flour, carcasses (neck with ribs) were thawed at room temperature $\left(25^{\circ} \mathrm{C}\right)$ for $3 \mathrm{~h}$, and their heads and fins were removed. Afterwards, carcasses were washed and immersed in $20 \%$ brine with fresh rosemary extract ( 1 herb:25 water) for $45 \mathrm{~min}$. The carcasses were then drained for $1 \mathrm{~h}$ and subjected to partial drying at $50^{\circ} \mathrm{C}$ for $60 \mathrm{~min}$. To complete the process, smoke was then added to the carcasses for $3 \mathrm{~h}\left(60\right.$ to $\left.80^{\circ} \mathrm{C}\right)$. The smoke was generated by friction outside of the smoking chamber. Eucalyptus trees (Eucalyptus globulus Labill.) were used as fuel for the production of smoke, for rafters $\left(8 \times 8 \times 80 \mathrm{~cm}^{3}\right.$ length), and for maintaining the temperature.

The carcasses were then pressed in a hydraulic press with a capacity of 10 tons, ground into smaller particles, dehydrated $\left(24 \mathrm{~h}\right.$ at $\left.60^{\circ} \mathrm{C}\right)$, and subsequently submitted to a new series of grinding with a mill type knife.

An Inbramaq extruder (Model IB-50-2009, nominal capacity of $50 \mathrm{~kg} / \mathrm{h}$; Inbramaq, Ribeirão Preto, Brazil) was used in order to develop the extruded snacks.

For the experiment, a completely randomized design containing five fish flour treatments (Trat1 $=0 \%$, Trat $2=3 \%$, Trat $3=6 \%$, Trat $4=9 \%$, and Trat $5=12 \%$ ) was implemented. The mixture of corn grits and flavored fish flour used in the extrusion of snacks included these different percentages of flavored fish flour (Figure 1).

The mixtures were added directly at the entrance of the extrusion system (shirt and thread) by a dispenser suitable for small samples. Thus, it was possible to work with samples of only 1,000 g.

For the extrusion process, the following processing parameters were initially used: die plate-two holes with center cut; chain of main motor-15 to $22 \mathrm{~A}$; inverter of the cutting knife- $5 \mathrm{~A}$; and rotameter of the homogenizer: $20 \mathrm{~mL} / \mathrm{min}$. The temperature applied by the machine during the extrusion process was $110^{\circ} \mathrm{C}$.

After preparing the extruded snacks, the samples were separated to analyze the chemical composition, colorimetry, water activity, sensory and microbiologic components, and TBARS from 30 to 120 days.

The analyses of chemical composition were performed on six replicates of flavored fish flour and on the extruded snacks created from the different treatments.

The samples were crushed in a multiprocessor to obtain a homogeneous mixture. Aliquots of these samples were used in the determination of chemical composition and minerals.

The moisture, crude protein, ether extract, and ash contents were determined according to AOAC (1995). An analysis of total fibers was performed according to the enzymatic-gravimetric method that was proposed by Instituto Adolfo Lutz (2008), while the determination of carbohydrates was performed by calculating the difference between total content and other components (moisture, crude protein, 


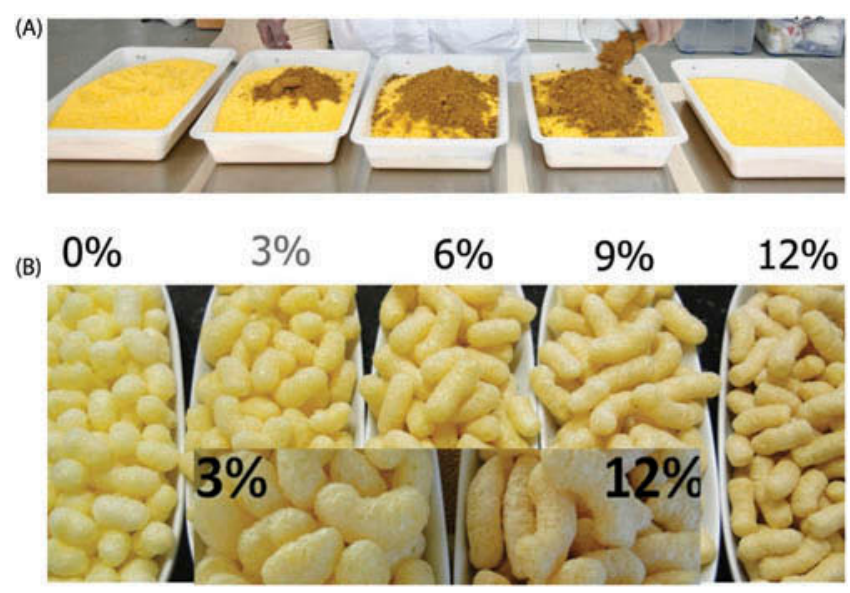

Figure 1. Development of extruded snacks: flavored fish flour included in the corn grits (A), extruded snacks with different inclusion levels $(0,3,6,9$, and $12 \%)$ of fish flour (B).

ether extract, and ash). The total caloric value was obtained by multiplying the sum of the mean values of protein, lipids, and carbohydrates by the factors 4, 9, and 4, respectively (Souci et al., 2000).

To conduct the analyses for calcium and iron, the sample digestion was performed in acid and determinations were performed via atomic absorption spectrometry with flame (FAAS), based on the procedure described by Zhou et al. (1998). Total phosphorus measurements were determined by using ammonium phosphomolybdate and spectrometry UV-VIS (Eijsink et al., 1997). AquaLab LITE Number AL1480 (Decagon Devices, Inc., Pullman, WA, USA) was used to determine water activity. All analyses were performed in triplicate.

To monitor the shelf life of extruded snacks, the oxidative rancidity test was performed by analyzing TBARS (expressed as mg malonaldehyde/kg; Vyncke, 1970) each month for a period of $30-120$ days. The extruded snacks were packed in plastic bags and stored at room temperature $\left(25^{\circ}\right.$ C) inside a cardboard box from June to September.

The color of the extruded snacks was determined with the help of a portable colorimeter (Model MiniScan EZ; Hunter Associates Laboratory, Inc., Reston, VA, USA). The light source was D65, the observation angle was $10^{\circ}$, the opening of the measuring cell was $30 \mathrm{~mm}$, and we used the $L^{\star}, a^{\star}, b^{*}$ scale of the CIELab system that was developed by Judd and Hunter (Hunter, 1975).

The $L^{\star}$ value represents the brightness of the snacks' color $\left(L^{\star}=0\right.$ corresponds to black and $L^{\star}=$ 100 corresponds to white), while $a^{*}$ and $b^{*}$ represent the saturation (chroma or purity) and hue (color). The values of $a^{\star}$ range from $-a^{\star}$ (green) to $+a^{\star}$ (red), while $b^{\star}$ values vary from $-b^{\star}$ (blue) to $+b^{\star}$ (yellow). The instrument calibration was performed prior to reading the samples with standard white and one black. Four readings were conducted for each sample.

To analyze the sensory components, samples of the extruded snacks ( $\pm 10 \mathrm{~g}$ ) were given to 40 untrained tasters who then assessed their color (color of products), aroma (pleasantness of the smell or odor), texture (tactile feel, firmness/tenderness), flavor (fundamental taste sensation), appearance (cleanliness and attractiveness), and general acceptability (general feeling of good or bad). These analyses were carried out in a maximum period of $24 \mathrm{~h}$ after the preparation of the extruded snacks. During the test, the samples were placed in small plastic cups (coffee type cups), packaged in plastic film, identified by five randomized numbers each and offered to the tasters. The tasters received all samples simultaneously (five treatments), and they were instructed to assess sample by sample. The tasters were instructed to use water to remove residual flavor of mouth between the samples. The tasters were given a card to rate the components with a 9-point hedonic scale ranging from 1 (dislike very much) to 9 (like very much; Moraes, 1993; Stone and Sidel, 1993; Dutcosky, 1996). 
Microbiological analyses were conducted on samples of extruded snacks from different treatments to determine the most probable number (MPN) of coliforms at $35^{\circ} \mathrm{C} / \mathrm{g}$, the MPN of coliforms at $45^{\circ} \mathrm{C} / \mathrm{g}$, the number of Staphylococcus coagulase positive in CFU/g, and Salmonella spp. (American Public Health Association [APHA], 1992).

To assess the effects of including different amounts of flavored fish flour on the chemical and mineral composition of the extruded snacks, we used the computer system SAS Proc GLM (SAS Institute. Inc., Cary, NC, USA). Dunnet's test was used to evaluate any differences among treatment means against the control, and regression analysis was used to evaluate the effect of including different levels of flavored fish flour in extruded snacks.

For the statistical analyses of data collected on sensory perception of the snacks, we used the computational system SAS Proc GENMOD (SAS Institute, Inc.). For sensory analysis, the error distribution was analyzed, and it was found that there is no normal distribution, so we used the procedure of generalized linear models. We considered that the distribution of the variables is a gamma function with a reverse link. We analyzed the effects of treatments and tasters by using regression analysis. To compare notes from tasters, we tested the inclusion levels against the control by mean test.

For TBARS, water activity, colorimetry, and microbiology of extruded snacks, descriptive analyses were performed based on the obtained results.

\section{Result and discussion}

The fish flour included in extruded snacks contained 5.04\% moisture, $45.50 \%$ crude protein, $14.60 \%$ ether extract, and $26.31 \%$ ash; these values were greater than the protein and ash values found by Souza (2006), which were 32.82 and $22.86 \%$, respectively. Crude protein and ash may differ depending on the source from which carcasses are obtained (depends on the feed provided to the fish), the filleting method used, the amount of meat in the carcass after removal of the fillet, and the presence or absence of ribs in the carcass; increasing the number of spines left in the carcass can contribute to an increase in the ash content of the flour.

The 5.04\% moisture value obtained in the fish flour is within an acceptable range according to the Regulation of Industrial and Sanitary Inspection of Animal Products (RIISPOA, 1997), as fish should not be more than $12 \%$ moisture.

The moisture content that was obtained was due to the 24 -h drying process at $60^{\circ} \mathrm{C}$ in a forced air oven, which was carried out after the grinding of the carcasses.

The moisture content value obtained in this study was much lower than values found by Souza (2006) in their preparation of flavored flour from carcasses of Nile tilapia. This is likely because the authors did not press the carcasses after the addition of smoke during the processing, before carcasses grinding to dehydration.

In addition, Matos (2009) reported that flour produced from the carcasses of Nile tilapia without the heads had $5.09 \%$ moisture and $33.05 \%$ total lipids. The moisture content reported by the authors is similar to that obtained in this experiment for the flavored flour; however, even though they used the same species of fish and carcasses minus the heads, the fat content was greater than that found in this experiment. This is also due to the fact that the authors did not press carcasses for flour or extract the excess fat, as was done in this experiment, where flavored carcasses were placed in a hydraulic press (capacity 10 tons) to extract the natural fat present in the fish. Also, Matos (2009) extracted lipids via the Bligh and Dyer (1959) method, which is a cold extraction, while this study used the Soxhlet method (Silva and Queiroz, 2002), which is a hot extraction that leads to greater loss of fat in the products.

The inclusion of flavored fish flour in extruded snacks showed no significant effect on the moisture content, with values ranging from 7.34 to $8.41 \%$ (Table 1). However, there was a significant increase in the levels of crude protein, ether extract, and ash when greater levels of fish flour were included. These results can be visualized in their estimated equations: $\hat{\mathrm{Y}}=6.43+0.402 \mathrm{Xi}$, 
Table 1. Chemical composition of fish flour and extruded snacks based on the level of fish flour included.

\begin{tabular}{|c|c|c|c|c|c|c|}
\hline Inclusion level $^{1}$ & Moisture (\%) & $\mathrm{CP}(\%)$ & $\mathrm{EE}(\%)$ & Ash (\%) & Estimated fiber (\%) & $\begin{array}{c}\text { Carbohydrate } \\
\text { (\%) }\end{array}$ \\
\hline $0 \%$ & 8.12 & 6.85 & 5.16 & 2.04 & 4.43 & 73.49 \\
\hline $3 \%$ & 8.41 & 7.86 & 5.98 & 2.31 & 4.30 & 70.97 \\
\hline $6 \%$ & 7.76 & 8.62 & 7.05 & 3.54 & 4.16 & 70.34 \\
\hline $9 \%$ & 7.34 & 10.28 & 7.24 & 3.97 & 4.03 & 67.73 \\
\hline $12 \%$ & 7.73 & 11.46 & 8.56 & 4.80 & 3.89 & 63.48 \\
\hline Flavored fish flour & 5.04 & 45.50 & 14.60 & 26.31 & - & 8.55 \\
\hline Significance & ns & * & * & * & - & * \\
\hline CV (\%) & 12.90 & 12.27 & 10.80 & 27.26 & - & 3.38 \\
\hline
\end{tabular}

${ }^{1}$ Fish flour inclusion level in the extruded snacks. ns $=$ not significant $(p>0.05)$. * Significant $(p<0.05)$.

$\hat{\mathrm{Y}}=5.18+0.267 \mathrm{Xi}$, and $\hat{\mathrm{Y}}=1.71+0.205 \mathrm{Xi}$, respectively. With increased amounts of fish flour included in the extruded snacks, a reduction in carbohydrate levels has been observed, as evident by the equation $\mathrm{Y}=73.85-0.7749 \mathrm{Xi}$. Also, there was a reduction in fiber content (4.43 to $3.98 \%$ ) with greater levels of fish flour. Despite this result, the extruded snacks can be considered as an important source of dietary fiber; it is important to note that these fiber levels are still in accordance with Ordinance No. 27, dated January 13, 1998-Technical Regulation on supplementary nutrition, where finished products must contain at least $3 \mathrm{~g}$ of fiber $100 \mathrm{~g}$ (Associação das Indústrias de Massas Alimentícias [Abima], 1998) in order to be fit for consumption.

Bombo (2006) reported that corn snacks had $7.45 \%$ of crude protein, while the corn snacks containing $30 \%$ linseed had $15.01 \%$ protein. The greater protein content associated with the inclusion of $30 \%$ linseed may be due to the high level of inclusion, which was greater than that of this experiment and also because linseed is a different protein source. The corn snacks prepared by Bombo (2006) contained $1.79 \%$ ash. In our experiment where we included flavored fish flour, the ash values were greater, mainly when we increased the level of flavored fish flour. The high amount of ash is due to the presence of spines in carcasses, which were included in the flour during processing and grinding.

According to Bombo (2006), the presence of small amounts of lipid facilitates the extrusion process and improves the texture. The extruded snacks that include flavored fish flour had lipid values greater than 5\%, which may have led to a reduction in the size of snacks because of a decrease in expansion. This increase in fat may also have caused a darkening of the snacks and therefore a decrease in the brightness value. The extrusion of snacks with higher levels of fish flour likely took longer, which provided greater Maillard reactions in snacks (Badrie and Mellowes, 1991) and consequently increased darkening.

In addition to the lipid content, several other factors can influence the extrusion process and thus the quality of the snacks. Some factors are the barrel temperature, screw speed, moisture, and fish flour content (Singh et al., 2014). These authors say that better quality snacks generally exhibit greater expansion and lower bulk density, and that there is an inverse relationship between expansion rate with the moisture and fish flour content. In their work, the authors determined that a proper expansion rate and bulk density occurs when 15-20\% of fish flour, 14-18\% of moisture content, barrel temperature of $100-1,100^{\circ} \mathrm{C}$, and screw speed of $360-480 \mathrm{rpm}$ is used.

Extruded snacks without the inclusion of fish flour had a caloric value of $367.8 \mathrm{kcal} / 100 \mathrm{~g}$, while the inclusion of different fish flour levels yielded a caloric value between 369.14 to $379.29 \mathrm{kcal} / 100 \mathrm{~g}$. According to Carvalho and colleagues (2012), the extruded snacks may be considered as an energy product since they have a large carbohydrate content. In addition, caloric values increase during the tempering process, because this process adds salt and the desired flavor while using a vegetable oil as a fixing agent (Capriles et al., 2007). Keeping this in mind, according to these authors, commercial corn snack samples have caloric values of $467.2 \pm 105.2 \mathrm{kcal} / 100 \mathrm{~g}$, while all of the snacks produced during this study have lower caloric values. 
Table 2. Mineral contents of fish flour and extruded snacks including fish flour.

\begin{tabular}{|c|c|c|c|c|c|}
\hline Inclusion level $^{1}$ & Calcium $(\mathrm{g} / 100 \mathrm{~g})$ & Phosphorus (g/100 g) & Iron $(\mathrm{mg} / 100 \mathrm{~g})$ & Magnesium $(\mathrm{g} / 100 \mathrm{~g})$ & Sodium $(\mathrm{g} / 100 \mathrm{~g})$ \\
\hline $0 \%$ & 0.097 & 0.026 & 5.99 & 0.010 & 1.49 \\
\hline $3 \%$ & 0.154 & 0.126 & 7.95 & 0.012 & 1.30 \\
\hline $6 \%$ & 0.357 & 0.217 & 8.12 & 0.015 & 1.14 \\
\hline $9 \%$ & 0.554 & 0.344 & 9.08 & 0.018 & 1.21 \\
\hline $12 \%$ & 0.728 & 0.440 & 11.19 & 0.016 & 1.16 \\
\hline Fish flour & 6.57 & 3.52 & 6.36 & 0.14 & 1.12 \\
\hline Significance & * & * & * & * & * \\
\hline CV (\%) & 15.48 & 21.56 & 16.38 & 20.07 & 7.15 \\
\hline
\end{tabular}

${ }^{1}$ Fish flour inclusion level in the extruded snacks. ${ }^{*}$ Significant $(p<0.05)$.

The analyses of minerals displayed a linear increase (calcium, phosphorus, magnesium, iron, and zinc) in relation to the inclusion of fish flour in the extruded snacks (Table 2). This linear effect can be seen through the regression equations: $\hat{\mathrm{Y}}=0.034+0.054 \mathrm{Xi}$ for calcium, $\hat{\mathrm{Y}}=0.0276+0.0335 \mathrm{Xi}$ for phosphorus, $\hat{\mathrm{Y}}=6.12+0.387 \mathrm{Xi}$ for iron, $\hat{\mathrm{Y}}=0.01+0.00056 \mathrm{Xi}$ for magnesium, and $\hat{Y}=0.21+0.023 \mathrm{Xi}$ for zinc. We observed a quadratic equation for sodium. This is most likely due to the nonuniform fixation of sodium chloride and condiments that were then added with the oil during the tempering process; this might have led to an accumulation of oil on the walls of the equipment, thereby reducing the amount of salt (Table 2). For magnesium, there was a variation of 0.010 to $0.016 \mathrm{~g} / 100 \mathrm{~g}$, while zinc varied between 1.00 to $1.25 \mathrm{mg} / 100 \mathrm{~g}$.

According to Matos (2009), flour prepared from Nile tilapia carcasses without heads contained $4.10 \mathrm{~g} / 100 \mathrm{~g}$ of calcium, $2.69 \mathrm{~g} / 100 \mathrm{~g}$ of phosphorus, and $3.44 \mathrm{mg} / 100 \mathrm{~g}$ of iron. The reported mineral contents (calcium, phosphorus, and iron) were lower in the literature compared to those values obtained in this experiment with fish flour (Table 2). The flour prepared in this study yielded $0.14,0.42$, and $1.12 \mathrm{~g} / 100 \mathrm{~g}$ of magnesium, zinc, and sodium, respectively. The flour from carcasses yielded 0.46 of water activity (Aw), which was greater than Matos' (2009) Aw value of 0.34.

The extruded snacks had a low Aw value, and snacks that included fish flour had values ranging from 0.50 to $0.53 \mathrm{Aw}$, while snacks with no flour ( $0 \%$ inclusion) yielded an Aw of 0.57 . Therefore, including flour in the extruded snacks caused a reduction in the water activity of snacks. These Aw levels are considered safe, therefore ensuring microbiological stability. These snacks can be classified as food with low water activity, because this class contains less than $20 \%$ moisture content and has a water activity under 0.60 (Uboldi-Eiroa, 1981).

There was a significant effect of treatment on brightness and chroma $a^{*}$; the regression equations were linear for these variables, where brightness $\hat{Y}=79.097-0.508 \mathrm{Xi}(p<0.0001)$ and chroma $a^{*} \hat{Y}$ $=0.67+0.295 \mathrm{Xi}(p<0.0001)$. We observed that the more flour that was included in the snack, the lower the light intensity was in the snack ( $0 \%$ of fish flour inclusion $L^{\star}=79.12 ; 12 \%$ of inclusion $L^{\star}$ $=73.63$ ). The snacks also presented with a darker color with the addition of flavored fish flour. For the chroma $a^{\star}$, an increase in the level of flour also increased the scale of the color red; because the numbers were very low (1.80 to 3.72), the color was a subtle red tint.

We observed a quadratic effect for chroma $b^{\star}\left(\hat{\mathrm{Y}}=29.09+0.60 \mathrm{Xi}-0.051 \mathrm{Xi}^{2}\right)$. The snacks with $3 \%$ of fish flour included demonstrated a greater intensity of yellow color; we also observed that an increase in flavored fish flour in the snacks led to a decrease in the yellow intensity or shade (3\% of inclusion - chroma $b^{*}=31.15,12 \%$ of inclusion chroma $\left.b^{*}=29.03\right)$. Snacks without the inclusion of flour had the lightest yellow shade compared to all of the elaborate snacks $\left(b^{\star}=28.8\right)$.

According to Leonel et al. (2010), extruded snacks that are based on sweet starches and orange fiber had a brightness from 68.25 to 79.78 , while the chroma $a^{*}$ values of 2.52 to 5.54 indicated the presence of red color in all samples. For chroma $b^{*}$, values ranged between 16.69 and 23.64, which indicates a strong presence of yellow color in the samples. In this experiment, where fish flour was included in the snacks, greater values of brightness (lighter) and chroma $b^{\star}$ (higher intensity of the yellow color) and lower values of chroma $a^{\star}$ (low pigmentation of red) were observed when compared to those reported by Leonel et al. (2010), regardless of the inclusion level. 
Every food product has a shelf life where it best retains its quality characteristics for consumption. For extruded snacks, TBARS was used in order to determine the shelf life. By quantifying the level of oxidation of lipids, we can compare our values to those of Kelleher et al. (1994), who found that TBARS values between 0.9 to $1.5 \mathrm{mg}$ of malonaldehyde/ $\mathrm{kg}$ are accompanied by a disagreeable odor.

Rancid odors occur when TBARS values are greater than $1.5 \mathrm{mg} / \mathrm{kg}$ of malonaldehyde $/ \mathrm{kg}$ sample. TBARS values, among other factors, are related to the type of product analyzed. Fish generally has higher TBA values than other meats due to its composition rich in long chain polyunsaturated fatty acids (Osawa et al., 2005). There is not a value of TBARS established in legislation as safe for human consumption; however, despite the varied results that are found in the literature, Greene and Cumuze (1982) reported $2 \mathrm{mg}$ of malonaldehyde/kg as threshold value. However, in this experiment with extruded snacks, analyses of TBARS were conducted at 30 days into the experiment and even though the levels ranged between 1.7 to $2.97 \mathrm{mg} / \mathrm{kg}$, there was no detectable oxidative rancidity. This detection was probably not perceived due to the use of spices and flavorings in the preparation of the snacks. However, after 60 days, there was a rapid increase in TBARS values, which ranged from 4.20 to $7.47 \mathrm{mg}$ malonaldehyde $/ \mathrm{kg}$. After this period, there was a decrease in the level of TBARS between 60 to 90 days (Figure 2). According to Seo (1976), this initial increase followed by a decrease in TBARS after a storage period can be attributed to reactions of muscle proteins with malondialdehyde; this is produced during the oxidation of fats, which prevents its detection during the time of analysis.

The addition of fish flour led to increased TBARS values. This can be due to the presence of polyunsaturated fatty acids with faster lipid oxidation, which could cause changes in the sensory quality and nutritional value, and even reduce the shelf life of snacks. The shelf life possibly could be extended with the use of additives and antioxidants in the preparation of both fish flour and at the time of mixing ingredients for snack extrusion (fish flour, corn grits, and water).

The fact that snacks had a low water activity may have facilitated the oxidation of lipids. According to Sgarbieri (1996), an Aw less than 0.3 virtually eliminates all degradative reactions in food; however, there is some lipid oxidation with minimal intensity at water activities between 0.3 and 0.4 , but which increases quickly in water activities both above and below this range. In this experiment, as mentioned, the Aw was above 0.5 .

There was no significant effect of the inclusion of fish flour on sensory parameters (Table 3 ). The tasters were unable to identify differences in aroma, flavor, appearance, texture, and color

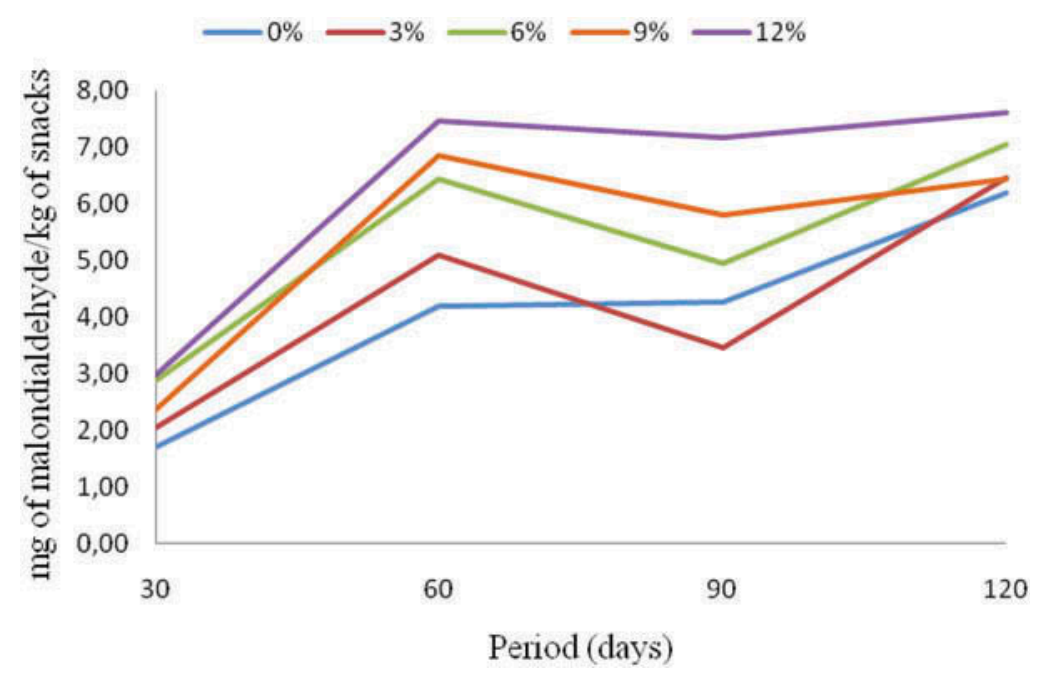

Figure 2. Thiobarbituric acid reactive substances values of extruded snacks that include flavored fish flour between 30 to 120 days. 
Table 3. Sensory analysis of extruded snacks with the inclusion of fish flour.

\begin{tabular}{lcccccc}
\hline Inclusion level $^{1}$ & Aroma & Flavor & Appearance & Texture & Color & General acceptance \\
\hline 0\% flour inclusion & 6.92 & 7.25 & 7.82 & 7.82 & 7.97 & 7.45 \\
3\% flour inclusion & 7.00 & 7.42 & 7.75 & 7.50 & 7.92 & 7.57 \\
6\% flour inclusion & 7.25 & 7.62 & 7.95 & 7.97 & 7.95 & 7.80 \\
9\% flour inclusion & 7.52 & 7.57 & 7.82 & 8.15 & 7.85 & 7.72 \\
$12 \%$ flour inclusion & 7.25 & 7.42 & 7.70 & 7.92 & 7.50 & 7.65 \\
Significance & ns & ns & ns & ns & ns & ns \\
\hline
\end{tabular}

${ }^{1}$ Fish flour inclusion level in the extruded snacks. ns $=$ not significant $(p>0.05)$.

Table 4. Microbiological analyses of fish flour and of extruded snacks containing fish flour.

\begin{tabular}{|c|c|c|c|c|}
\hline Inclusion level $^{1}$ & $\begin{array}{l}\text { Most probable number of } \\
\text { coliforms at } 35^{\circ} \mathrm{C}(\mathrm{NMP} / \mathrm{g})\end{array}$ & $\begin{array}{l}\text { Most probable number of } \\
\text { coliforms at } 45^{\circ} \mathrm{C}(\mathrm{NMP} / \mathrm{g})\end{array}$ & $\begin{array}{c}\text { Count of } \\
\text { Staphylococcus } \\
\text { aureus (UFC/g) }\end{array}$ & $\begin{array}{c}\text { Search of } \\
\text { Salmonella ssp. } \\
\text { in } 25 \mathrm{~g}\end{array}$ \\
\hline $0 \%$ flour inclusion & $<3$ & $<3$ & $<1 \times 10^{2}$ & Absent \\
\hline $3 \%$ flour inclusion & $<3$ & $<3$ & $<1 \times 10^{2}$ & Absent \\
\hline $6 \%$ flour inclusion & $<3$ & $<3$ & $<1 \times 10^{2}$ & Absent \\
\hline $9 \%$ flour inclusion & $<3$ & $<3$ & $<1 \times 10^{2}$ & Absent \\
\hline $12 \%$ flour inclusion & $<3$ & $<3$ & $<1 \times 10^{2}$ & Absent \\
\hline Fish flour & $<3$ & $<3$ & $<1 \times 10^{2}$ & Absent \\
\hline
\end{tabular}

${ }^{1}$ Fish flour inclusion level in the extruded snacks.

between snacks of different treatments (different levels of flour included in snacks). Therefore, there also was no significant difference in the general acceptance of the extruded snacks. The taster would consume any of the elaborate snacks, but the most beneficial snack to consume would be the one with the greatest inclusion level, as these snacks contained greater levels of nutrients such as protein and minerals, and they had a lower carbohydrate content. The scores given by the evaluators indicating how much they enjoyed the snacks were around 7 and 8 , which corresponds, respectively, to "enjoyed regularly" and "like very much."

The microbiological analyses of extruded snacks indicated a reduction in the number of coliforms at 35 and $45^{\circ} \mathrm{C}$, reduced numbers of Staphylococcus aureus, and an absence of Salmonella (Table 4), thereby indicating that the snacks are suitable for human consumption, and that they follow the microbiological standards required by law.

These extruded snacks are a viable option in the diets of children, especially because they consume a lot of corn snacks ("chips") which generally are only based on corn; however, the product from this study has a greater nutritional value compared to snacks found in the supermarket that have no fish flour.

\section{Conclusion}

The inclusion of flavored fish flour improved the nutritional value of extruded snacks, as we observed increased levels of protein, lipid, ash, and minerals without significant negative effects on the sensory characteristics. The extruded snacks are microbiologically within the standards required by law, and are ready for consumption. They are a good option for human consumption, as they are a more nutritious product with a greater nutritional value compared to snacks that have no fish flour.

\section{References}

ABIMA. 1998. Portaria n²7, de 13 de janeiro de 1998. Retrieved from http://www.abima.com.br/dload/13_60_port_ 27_98_leg_alim_nac.pdf

AOAC. 1995. Official Methods of Analysis of the Association of Official Analytical Chemists. Arlington, VA: Author. APHA. 1992. Compendium of Methods for the Microbiological Examination of Foods. Washington, DC: Author. 
Badrie, N., and Mellowes, W. A. 1991. Effect of extrusion variables on cassava extrudates. J. Food Sci. 56: $1334-1337$.

Bligh, E. G., and Dyer, W. J. 1959. A rapid method of total lipid extraction and purification. Can. J. Biochem. 37: 911-917.

Bombo, A. J. 2006. Obtenção e caracterização nutricional de snacks de milho (Zea mays L.) e linhaça (Linum usitatissimum L.), (Doctoral thesis). Universidade Estadual de São Paulo, São Paulo, Brazil.

Capriles, V. D., Soares, R. A. M., and Arêas, J. A. G. 2007. Development and assessment of acceptability and nutritional properties of a light snack. Ciência Tecnol. Alim. 27: 562-566.

Carvalho, A. V., Bassinello, P. Z., Mattietto, R. A., Carvalho, R. N., Rios, A. O., and Seccadio, L. L. 2012. Processamento e caracterização de snack extrudado a partir de farinhas de quirera de arroz e de bandinha de feijão. Braz. J. Food Technol. 15: 72-83.

Dutcosky, S. D. 1996. Análise Sensorial de Alimentos. Curitiba, Brazil: Champagnat.

Eijsink, L. M., Krom, M. D., and Lange, G. J. 1997. The use of sequential extraction techniques for sedimentary phosphorus in eastern Mediterranean sediments. Mar. Geol. 139: 147-155.

Greene, B. E., and Cumuze, T. H. 1982. Relationship between TBA numbers and inexperienced panelists'assessments of oxidized flavor in cooked beef. J. Food Sci. 47(1): 52-54.

Hildsorf, A. W. S. 1995. Genética e cultivo de tilápias vermelhas, uma revisão. Bol. Inst. Pesca 22: 73-78.

Hunter, R. S. 1975. The Measurement of Appearence. New York, NY: John Wiley.

Instituto Adolfo Lutz. 2008. Métodos Físico-Químicos para Análise de Alimentos. São Paulo, Brazil: Author.

Kelleher, S. D., Hultin, H., and Wilhen, K. A. 1994. Stability of mackerel surimi prepared under lipid stabilizing processing conditions. J. Food Sci. 59: 269-271.

Leonel, M., Souza, L. B., and Mishan, M. M. 2010. Produção de snacks extrusados á base de polvilho doce e fibra de laranja. Rev. Ciênc. Rural 40: 1411-1417.

Matos, L. F. 2009. Avaliação química e sensorial da farinha de peixe aromatizada para consumo humano, a partir de carcaças de tilápia do Nilo (Oreochromis niloticus) com e sem cabeça. Paper presented at $46^{\circ}$ Reunião Anual da Sociedade Brasileira de Zotecnia, Maringá, Brazil.

Moraes, M. A. C. 1993. Métodos para Avaliação Sensorial dos Alimentos. Campinas, Brazil: UNICAMP.

Ogawa, M., and Maia, E. 1999. Manual de Pesca-Ciência e Tecnologia do Pescado. São Paulo, Brazil: Livraria Varela.

Osawa, C. C., Felício, P. E., and Gonçalves, L. A. G. 2005. Teste de TBA aplicado a carnes e derivados: Métodos tradicionais, modificados e alternativos. Quím. Nova 28(4): 655-663.

RIISPOA. 1997. Regulamento da Inspeção Industrial e Sanitária de Produtos de Origem Animal. Ministério da Agricultura, Pecuária e Abastecimento, Brazil. Seção II-Derivado do Pescado, Artigo 466.

Seo, C. W. 1976. Hydrocarbon production from freeze dried meats. J. Food Sci. 41: 594-597.

Sgarbieri, V. C. 1996. Proteínas em Alimentos Protéicos: Propriedades-Degradações-Modificações. São Paulo, Brazil: Livraria Varela.

Silva, D. J., and Queiroz, A. C. 2002. Análise de Alimentos: Métodos Químicos e Biológicos. Viçosa, Brazil: Universidade Federal de Viçosa.

Singh, R. K. R., Majumdar, R. K., and Venkateshwarlu, G. 2014. Optimum extrusion-cooking conditions for improving physical properties of fish-cereal based snacks by response surface methodology. J. Food Sci. Tech. 51(9): 1827-1836.

Souci, S. W., Fachman, H., and Kraut, E. 2000. Foods Composition and Nutrition Tables. Stuttgart, Germany: Medpharm Scientific Publishers.

Souza, M. L. R. 2006. Farinha de Carcaça de Peixe com Ervas Aromáticas para Alimentação Humana (CD-ROM, No. 2590). Bento Gonçalves, Brazil: Aquabio.

Stone, H., and Sidel, J. L. 1993. Sensory Evaluation Practices. San Diego, CA: Academic Press.

Uboldi-Eiroa, M. N. 1981. Atividade de água: Influencia sobre o desenvolvimento de microrganismos e métodos de determinação em alimentos. Boletim do ITAL 3: 353-383.

Vidotti, R. M., and Borini, M. S. M. 2006. Aparas da filetagem da tilápia se transformam em polpa condimentada. Panorama da Aquicultura 16: 38-41.

Vyncke, W. 1970. Direct determination of the thiobarbituric acid value in trichloroacetic acid extracts of fish as a measure of oxidative rancidity. Fett. Wiss. Technol. 72: 1084-1087.

Zhou, H. Y., Cheng, E. Y. H., and Chank, K. M. 1998. Metal composition in sediments and tilapia collected from Island water of Hong Kong. Water Res. 32: 331-3340. 